\title{
'Mulheres Novas com Cabeças Limpas': Pitfalls of the Revolution in Licínio de Azevedo's Virgem Margarida
}

MARIA TAVARES

Queen's University, Belfast

\begin{abstract}
In this article, I focus on Licinio de Azevedo's 2012 film, Virgem Margarida, in relation to Frelimo's policy of forced re-education camps and their effects on marginalized women in 1980s Mozambique. I also examine the recent political instability in Mozambique and the gendered legacies of regional sentiments on Mozambican national identity.
\end{abstract}

Keywords: Mozambique; Frelimo; Gender; Cinema; Memory

"The essence of a nation is that all individuals have many things in common, and also that they have forgotten many things" (Renan 11).

"The beauty of memory is that it is imprecise enough to be appropriated by unexpected hands, to connect apparently unrelated topics, to explain anew old problems" (Confino 1387).

The study of collective memory formation and the ways in which people come to make sense of the past in post-conflict Mozambique is still a field under development. This fact points to a need to understand which stories are being remembered, which memories are being forgotten, and what purposes such 
movements serve in contemporary society. As the historian Alon Confino reminds us, "the often made contention that the past is constructed not as a fact but as myth to serve the interest of a particular community may still sound radical to some, but it cannot (and should not) stupefy most historians" (1387).

In this article, I provide a close reading of Licínio de Azevedo's Virgem Margarida (2012), a film that closely examines the construction of the Mozambican nation immediately after independence. By going back to this very particular moment of Mozambican history, Azevedo not only examines the utopian ideal of the Mozambican nation under construction, revealing its tendency to exile rather than integrate, but also sheds light on one of the most controversial and under-explored Frelimo socio-political programs: the reeducation centers. At the same time, and following art historian and cultural theorist Aby Warburg's proposal, I argue that Azevedo's work cannot be fully understood in isolation from its own context of emergence.

\section{"Virgem Margarida": the artist and the work of art}

Born in Porto Alegre, Brazil, in 1951, Licínio de Azevedo is considered to be "o cineasta de maior renome" in Mozambique (Convents 520). Having graduated in journalism during the Brazilian dictatorship, Azevedo published in Folha da Manhã, a left-wing magazine, soon realizing that censorship's constraints would not allow him to publish about the then ongoing liberation struggles in Africa (Convents 521). Soon after the end of the anti-colonial struggle in Lusophone Africa, Azevedo travelled to Guinea-Bissau, where he co-wrote Diário da Libertação, and later to Mozambique, following an invitation from writer and filmmaker Ruy Guerra, once again to collect and register stories of the liberation struggle (Azevedo and Rodrigues; Azevedo, Relatos). He has stayed there to this day. Azevedo worked for some time at the ICS (Instituto de Comunicação Social), and he was later involved in Kuxakanema (Birth of cinema), a project of the Instituto Nacional de Cinema (INC) that sought to bring cinema to all parts of the newly born nation-state and to promote Frelimo's revolutionary ideals. His transition from journalism to literature and cinema was, in his own words, "um processo natural, suave e sem traumas" (“Construir Salas"). According to Guido Convents, however, meeting Jean-Luc Godard in 1978 was a turning point in the director's career (522). Godard had been invited by Jacinto Veloso, the then 
Minister for Security, to design a project that would ultimately aim at decolonizing Mozambican television and cinema (Gray 149). Even though Godard's project was eventually rejected by the State for being unfeasible, the filmmaker left his mark on the generation of filmmakers that subsequently emerged:

Licínio de Azevedo descobre, assim, as novas tecnologias e as possibilidades do vídeo, comparadas com as do filme de $16 \mathrm{~mm}$ e acredita que este será o meio do futuro. Para um cineasta com poucos recursos, o vídeo parece ser a solução. Ao contrário de muitos outros cineastas moçambicanos, o brasileiro-moçambicano Licínio de Azevedo faz ele próprio os filmes que quer. Não obedece totalmente às orientações do partido, segundo as quais o documentário é a melhor maneira de chegar ao povo. (Convents 522)

Azevedo directed his first fictional short-movie in 1986 and co-founded the production company Ébano Multimédia in 1990. His main filmography includes eighteen titles (documentaries and short films) and he has won various international awards. Virgem Margarida is his first feature film.

The film opens up the debate on the controversial re-education centers, implemented by Frelimo immediately after independence with the purpose of creating the socialist "homem novo" and "mulher nova." It focuses on prostitutes, one of the groups targeted in the process of "cleansing" the urban space. In 1978, Azevedo saw a picture of a prostitute being escorted by two soldiers, taken by the Mozambican photographer Ricardo Rangel (1924-2009) and titled, A Última Prostituta (Yeboah, "Resilient Whores"). He used it as the basis for his 1999 homonymous documentary co-directed with Isabel de Noronha. The documentary provides the testimony of five women who were deported at the time, giving them the opportunity to share their experiences and grievances regarding the event, but also to unveil micro-histories that would otherwise remain unknown, such as those of women mistaken for prostitutes and taken away for "re-education." ${ }^{1}$ This was the case of the virgin Margarida, "a

\footnotetext{
${ }^{1}$ Commenting on the documentary, Azevedo states: "Quando falam sobre a violência a que foram sujeitas, choram. No filme, elas choram.... "É a primeira vez que elas se
} 
personagem mais real do filme," in the words of Azevedo, whose real story inspired the making of the fictional feature film Virgem Margarida ("Do jornalismo ao cinema”). A co-production between Mozambique, Portugal, and France, the movie was filmed in Maputo and in Sussudenga, Manica province, and the director chose mostly non-professional actors. Its premiere was at the Toronto International Film Festival, in September 2012. Virgem Margarida circulated internationally, accumulating numerous important awards, before it was shown in Mozambique, where it was screened for the first time in April 2013, during the first Maputo African Film Week. According to Azevedo, the choice of an international premiere was made by the producers as a matter of precaution due to the movie's theme:

Foi uma opção dos produtores. Penso que havia um sentimento errado de que o filme podia ser polémico, por tratar de um ambiente político que ainda não havia sido discutido. Os produtores quiseram, primeiro, ver qual seria a recepção do filme fora. $O$ filme estreou primeiro no Canadá e depois em vários festivais internacionais. Ganhou prémios e, quando chegou aqui, foi bem recebido. ("Do jornalismo ao cinema”)

The film tells the story of Margarida, a sixteen-year-old girl who is captured, along with other women, by Frelimo soldiers who have just arrived in the city from the battle fronts in remote areas of the countryside and are eager to eradicate from society any behavior they consider deviant and associated with the corrupt colonial regime. Prostitution is high on their list of targets. The women are removed from the urban setting and taken to a re-education center in the distant province of Niassa, where they are to build a new village from scratch, under the supervision of female Frelimo soldiers. They are simultaneously to be reeducated so as to embody the revolutionary ideal of "Mulher Nova," the only one the governing party deems suitable for the society it envisions. It soon becomes clear that even though not all the women in the group are prostitutes, it is their perceived behavioral deviation from the established norm that leads to their

exprimem, nunca tinham tido a oportunidade de falar sobre isso abertamente $\ldots$ os testemunhos mostram a revolta total, absoluta" (Cordeiro, "O Inimigo de Dentro da Revolução"). 
detention: Susana is a single mother who is also a professional dancer; Luísa is a young and modern woman whose boyfriend is a white Portuguese man about to leave Mozambique; and, finally, Margarida is a young illiterate bride-to-be from the countryside who is arrested for failing to provide official identification documents when approached by a soldier at the market where she intends to acquire her trousseau.

The main action takes place in the re-education center, focusing on the dislocated women's struggle to adapt and survive in their new and inhospitable setting. The film also recounts the tensions arising from the coexistence of three identifiably different groups of women: Southerners, Northerners, and the soldiers. This difficult interaction emerges as a moment of knowledge exchange and sharing for the women, with the questioning of some cultural and ideological preconceptions. Ultimately, the bonds of solidarity between the women prevail due to the emergence of a common enemy who seals the fate of the virgin Margarida. Margarida's rape by Commander Felisberto, the highest local government authority, unveils the women's shared condition of marginality within the gender-blind revolutionary discourse of Frelimo, and it prompts them to put an end to the re-education center.

Virgem Margarida's proposal for revisiting Frelimo's controversial reeducation centers invites the viewer to engage with the film in multiple ways. In this essay, I focus on the problematization of memory through a two-fold analytical exercise. At one level, I argue that the retrieval of such an obscure moment allows for the emergence of marginalized micro-histories that question and destabilize official versions of history. At a second level, I demonstrate that the establishment of this space for reflection on historical processes in contemporary society enables the (re)opening of the debate on national identity and, subsequently, the emergence of alternative sites of resistance from which a different future can be imagined.

\section{Pitfalls of the revolution: making and unmaking history}

Frelimo's preoccupation with the development of an educational project within what would later become the Mozambican nation-state dates back to the party's first congress, in September 1962, in Dar es Salaam (Zawangoni 25-29). It was not until 1968, however, when the liberation front's second congress took place, 
that Frelimo would establish its educational policies and strategies around two main goals: the "Nova Sociedade" and the "Homem Novo." (Zawangoni 36-37). This project aimed at making education accessible to all citizens through the "apropriação dos conceitos da educação e trabalho produtivo e da relação escolacomunidade consagrados nas reformas educacionais da época, em particular, pela UNESCO e pelos países socialistas do Leste europeu," and with a view to fulfilling the liberation front's immediate needs (Zawangoni 37). Having committed itself, at independence, to bringing about a socialist revolution that would radically break with the colonial past, Frelimo understood the important role education played in prompting the identification of the new citizens of the nation-state with the kind of citizenship that Frelimo had designed for Mozambique. In this respect, the party created a line of action that can be considered to be dual. On the one hand, Frelimo created the structures to make education available to all citizens, simultaneously developing official mechanisms to ensure tight control of the Ministry of Education over educational programs implemented throughout the country, as reflected in the imposition of a common language and a unique ideological program (Rothwell xv-xvi). On the other hand, Frelimo established specific structures in which those considered to be "dissidents" would have the opportunity to learn how to think and behave like "New Men" and "New Women," in order to find a place in this "New Society." These were the "centros de re-educação."

Very little is known or has been published to date about these centers, and the duration of the project remains to be determined with any accuracy. Historian Colin Darch's tracing of the theme in the local and foreign press at the time places the announcement of the project by Armando Guebuza, the then Minister of Internal Administration for the Transitional Government, in November 1974, and its suspension shortly after President Samora Machel's tour of the Cabo Delgado province, in late 1981, in which he observed various problems in the way the centers were functioning (“Centros de Reeducação, 1974-”). In Samora's view, the re-education centers were a legitimate and valuable tool for the transformation of society. They were the means through which dissidents could understand and overcome their deviation, become socially and politically engaged, and earn a place in the New Society (Darch, "Machel's Speech"; Machava 593-609). Nonetheless, as Sarah LeFanu points out in her work entitled $S$ is for Samora: A Lexical Biography of Samora Machel and the Mozambican 
Dream (2012), the mere definition of what constituted a deviation was problematic enough:

Grammatically, reeducado or reeducada means a man or woman who has been re-educated, but in Mozambique the word was used to mean someone currently undergoing re-education: it described the women in miniskirts and tight $\mathrm{t}$-shirts bumming cigarettes on the street corners of Lichinga, who looked as if they came from not just a different country from the local women in their patterned cotton capulanas with their babies swaddled on their backs, but from a different world entirely; and it described men in worn-out townie shoes waiting miserably in the hospital to be treated for the TB and sleeping sickness they would catch again as soon as they were back in the re-education camps. It described the Jehovah's Witnesses and their families, who, accepting no authority other than their God, refused to join in with Viva Frelimo! (215-16)

The re-education centers soon became a place for people who were indiscriminately deemed different, and for political dissidents, too (Machava 593-609). In addition, the atrocities committed at some of the camps, a few of which Samora was able to observe directly during his tour of Cabo Delgado, unveiled the gap between the idea of the project and its reality. Azevedo himself, in an interview with the Portuguese daily newspaper Público reproduced on the cultural website Buala, admitted that he too believed, at the time, that the revolution could purify the human being, ultimately leading to the emergence of a New Society ("Reeducação de Mulheres"). His need to understand more fully the thin line between utopia and dystopia, when it comes to retrieving and problematizing the memory of the complexities of the revolution, is one of the reasons for the creation of Virgem Margarida. In the director's words: “Agora quero compreender o lado humano destes processos, a contradição dos grandes ideais que, por vezes, se transformam em tragédias pois as pessoas que os dirigem são mais fracas do que os mesmos" ("Reeducação de Mulheres").

A focus on the tensions between collective memory and that of individuals constitutes the film's center. Its first image is a close shot of a puddle of water in which we gradually observe the emergence of a reflection, coming straight towards the camera - the inverted image of a truck carrying Frelimo supporters 
happily singing and waving banners with revolutionary messages. This upsidedown image, which is merely a reflection, eventually disappears when the actual truck drives over the puddle of water. The camera now closes up on the message of the front banner: "A Luta Continua." The almost overwhelming materiality of the truck completely dominates the screen, leaving the viewer nothing but the words "A Luta Continua" on which to focus. Such a choice points towards what Paul Ricoeur has referred to as "the handling of authorized, imposed, celebrated, commemorated history - of official history" (448). In this context, Albino's remark, in his interview for @Verdade, on how Mozambicans born in the late 1980s and 1990s wondered about how real the re-education camps had actually been, becomes particularly relevant (Azevedo, "Construir Salas”). It reveals that collective memory in Mozambique was persistently configured to present the socialist revolution in a positive light, and that the success of that process of configuration in forging subsequent individual memories depended on forgetting the "casualties of the revolution" (LeFanu 219). In light of such an interpretation, the puddle of water, in which we see the inverted reflection of the truck, becomes the locus of all the various forms of dystopia experienced by the different women in the movie. The retrieval of the silenced individual and gendered memories challenges in various ways the limits of official collective memory at the basis of a communal identity. It turns the celebration of official history and official memories upside down, hinting at its prevalence over any other versions of history, leaving no space for the emergence of other perceptions that might challenge its premises.

There are several instances in which the viewer is directed toward the pitfalls of revolutionary discourse, as well as to the challenges arising from Frelimo's post-independence colonial hangover. The immediate eradication of prostitution from the urban space as a first step in a revolutionary plan unveils one of the most controversial areas of Frelimo's socialist discourse: its lack of engagement with gender politics. Despite the emphasis put on women's liberation, during and after the anti-colonial struggle, it is made clear throughout the film that dangerous stereotypes remain alive in the New Society. ${ }^{2}$ The obsession with the idea of

\footnotetext{
${ }^{2}$ When discussing prostitution in the socialist period, Isaacman and Stefhan acknowledge that some unjust acts took place during the cleansing campaigns due to people's "overexcitement" with respect to the task: "Contudo, como acontece com muitas manifestações populares deste género, muitas pessoas entusiasmaram-se em demasia
} 
achieving purity in society by controlling women's bodies echoes the Estado Novo's posture towards women (Ferreira 133-44). Initially, we observe the supposed prostitutes being indiscriminately detained in the streets of Maputo, gathered in a warehouse and transported like animals by male soldiers. In all instances, they are treated poorly, threatened, provided with no information, prevented from speaking, and often humiliated. But it is not until the interaction between female and male soldiers comes under scrutiny that the contradictions at the core of Frelimo's discourse become clearer. When Commandant Maria João and her team of female soldiers prepare to abandon life in the bush, after more than a decade of fighting, in order to resume their civilian lives and form families, they are informed by their male superior, Commandant Felisberto, that they are to carry out one final mission for the revolution: the construction of a reeducation center for prostitutes coming from the corrupt cities. Although they do not question Felisberto's authority within the hierarchical military structure, they do refer to him as "uma punição": one that prevents them from enjoying the newly independent nation. Considering the historical development of the OMM (Organization of Mozambican Women), created in 1973 as a branch of the liberation front, the film hints at the fact that women's emancipation was regarded as primarily economic, which has left women in a very contradictory place within a modern society that is still dominated by men. If they were called upon actively to participate in the public sphere, they were also expected to identify with the party's more traditional notion of womanhood. As Isabel Casimiro points out, the 1975 Constitution still cast women's citizenship as a constrained one. While it gave women the right to vote, the right to two-months' maternity leave, and equality to men in terms of employment, salary, education, and justice, it also forced women to relinquish their Mozambican citizenship if they married a foreign citizen - a measure that did not apply to men (Casimiro 69-70). The film's female soldiers soon realized what they had in common with the detained women was greater than they could ever have predicted.

From the film's outset, the female soldiers emphasize knowledge as the key element that distinguishes them from the detained women: knowledge of what

com o seu trabalho e ocorreram algumas injustiças. Por isso, na cidade de Nampula, poe exemplo, a polícia e membros dos Grupos Dinamizadores, com o entusiasmo de erradicarem a prostituição, prenderam todas as mulheres que não tinham maridos, na suposição que todas as mulheres solteiras tinham que ser prostitutas" (125). 
the new nation is, knowledge of what it means to be a New Woman, and knowledge of what a woman's contribution to the New Society should be. They see themselves as harbingers of knowledge, who will pass on to the dissidents what they know of Frelimo's program to liberate them, at any cost, from the constraints of a colonial mindset, and bring them into modernity. Their goal is clear: they will create "Mulheres Novas com cabeças limpas" (Azevedo, Virgem Margarida). They recognize that the individual's needs are subordinate to the needs of the revolution, and yet they never question the program or the hierarchical structure that comes with it. Given their attitude, one cannot avoid creating a parallel between the soldiers' choice and OMM's posture after independence, as Casimiro reminds us: "a OMM é definida como um 'braço do Partido’ e funciona como linha de comunicação entre o Partido e o Povo. A sua política é a política da Frelimo, não cabendo nela, na maior parte das vezes, as lutas específicas de género" (73). It is, therefore, particularly relevant that when Commander Maria João introduces herself to the detainees, she imposes her authority by stressing that she is a woman who can also be "homem, muito mau para quem não obedecer." Furthermore, she explains that she was never given a choice and is merely following orders, and when asked about when the women should expect to leave the camp, she answers that that will not happen until orders from her superior, Felisberto, come through. Such a posture reveals that this new representation of women - the New Woman-is based on an emancipation achieved via masculinization. In addition, it unveils the fact that this New Woman is created as a companion of the New Man. She is allowed to participate in his world, but he remains in the position of decision-making-even in what relates to her own representation (Nhantumbo and Meneses 105-29).

The female soldiers set out to teach the women how to become New Women, and the interactions between detainers and detainees evolve in parallel as the film deconstructs Frelimo's socialist program. The forging of a society based on the non-recognition of ethnic, racial, or gender differences in order to convey a consistent image of national unity and fight regionalism along with tribalism materializes in the female soldiers' continuous attempts to strip the detained women of their identities and force them to accept their new reality through humiliation, torture, and punishment. As they learn how to be more like the female soldiers, they are constantly reminded that they are all women from the same nation who need to accept their new identity. Re-education soon reveals 
itself to be indoctrination. Women from the North and the South are forced to share the same barracks and are provided with identical dark grey uniforms. However, what Samora perceived to be a move toward making the re-educated Mozambican "understand that the life of one is connected with the lives of all" comes across in the film as an imposition of the collective to the detriment of the individual (Darch, "Machel's Speech"). Clear instances of this occur in the scene in which Maria João orders Margarida to remove the flower that she had embroidered on Susana's uniform (thus making it unique), or the scene in which all the women who had gone to the village are severely punished after Maria João's assistant, Sadimba, finds a bar of soap hidden under Ancha's bed. The women are tied to stakes under the blazing sun with no water and with their arms, legs, and eyes open. When Ancha asks to be allowed to go the latrine, Sadimba's reply is "Caga aí mesmo e para de fazer barulho."

Frelimo's emphasis on the move toward a modern society through a complete detachment from traditional values-perceived as obscure and obsolete, as well as a reminder of a colonial mindset-is challenged in Virgem Margarida. When a famished Laurinda steals and eats a chicken, her belly swells up as if she were pregnant, and chicken sounds come out of it. The other women claim that she is under the spell of the chicken's owner, and they ask the female soldiers for help in contacting him. Commander Maria João replies that the New Man does not recognize magic and only believes in science. Laurinda never gets help, and she ends up dying. Her death lays bare the problematic nature of Frelimo's post-independence socio-political program, which refused to discuss what it considered to be unacceptable. In the words of Casimiro: "A nova sociedade surgida no período pós-independência encerra rupturas com a sociedade colonial, mas também continuidades, produto do passado histórico, misturando dimensões tradicionais e coloniais que se retroalimentam, numa fase de desordem social, em direcção a uma 'sociedade de tipo novo' experimentada nas Zonas Libertadas da Frelimo” (58).

Their attachment to their previous lives eventually leads the Southern group to attempt an escape from the camp. The escape is unsuccessful, and it leads to the death of Susana, a single mother from Maputo who desperately tries to go back home upon receiving news that one of her children had passed away in her absence. The attempted escape also shows that the enforcement of a unitary communal stance ultimately translates into fragmentation; in particular, it ends 
up widening the antagonism between Northerners and Southerners when Mariamu and Ancha, representatives of the former group, denounce the Southern women to the female soldiers to avoid collective punishment.

The film's deconstruction of Frelimo's socialist program reaches a high point in relation to women's emancipation when Margarida's rape by Commander Felisberto exposes the consequences of overlooking gender. As Hilary Owen argues, women were conceptualized by Frelimo within a classic Marxist-Leninist framework, which was largely gender blind:

Frelimo endeavored to put into practice the classic Marxist-Leninist conceptualization of women's emancipation in economic terms, emphasizing women's historical and sociocultural oppression by colonial capitalism. This often-cited "productivist bias" advocated the economic liberation of women through their integration into the forces of production, particularly in non-traditional areas of waged labor. What the Marxist-Leninist project ignored, however, was the significance for women of the conditions of sexual reproduction since it notoriously lacked a theory of gender struggle, equivalent to the discourse of class struggle, with which to critique the patriarchal practices of men within the liberation movement itself. (33)

Although women were pushed into participating in the construction of the new nation, their role remained highly contradictory within Frelimo's discourse. The party's response to this was to discourage its discussion and generally devalue its importance. Women were expected to carry on performing their lifelong duties within the household while simultaneously embracing their new roles outside the household (Urdang 160-61). They were not to confront their husbands, nor expect them to share the household tasks or demand equality in the domestic sphere. As Urdang claims, they should always "speak with kind words" (161). In this context, the agency of OMM greatly contributed to the consolidation of these perceptions within society (Casimiro 55-84; Sheldon 142). As a result, Frelimo's depoliticization of the private sphere allowed for the maintenance and reinforcement of the patriarchal status quo. The creation of a male utopia was thus framed at the expense of women (Urdang 151-70; Sheldon 115-52; Scott 105-19). In Virgem Margarida, when both female soldiers and detainees are 
confronted with the flaws of the New Man (embodied by Commander Felisberto), it becomes clear to all that the enemy lies within.

Commander Felisberto is the local party representative who, along with the male administrator of the village, ensures the application of the party's directives in the region. Occupying the top place in the military hierarchical structure, he emerges as the only person who has power over the lives of both groups of women. Because he is the female soldiers' superior officer, he is responsible for forcing them to remain in the bush in order to build the re-education camp. $\mathrm{He}$ reminds Commander Maria João that "a nossa luta não termina com a independência. Não aprendeu isso, camarada? A independência é apenas uma etapa da luta de libertação do nosso povo, compreendeu?" In this way, he uses the party's rhetoric to defer any response to the female soldiers' demands, thus ensuring the propagation of an order in which he remains privileged. At no point in the film does Felisberto actively engage in work or instruction, while the female soldiers are continuously engaged in different tasks inside and outside the camp. In the few moments in which Felisberto is present, what becomes clear is that his mastery of the party's rhetoric enables him to use the power he enjoys for his own individual whims. First, he uses it to convince the female soldiers to perform one last mission for him. He then uses it to get sexual favors from Ancha in exchange for some soap. Finally, he uses it to take Margarida's virginity, despite his promise to take her back to her family. Ultimately, Felisberto becomes the epitome of the thirst for and misuse of power, a representation that replicates, to a certain extent, Frelimo's stance at the time in relation to the exclusive control of power in all spheres of life (Mosca 155). LeFanu recalls an episode, with reference to the re-education camps, that echoes Felisberto's behavior towards the detainees:

When we arrive we find a disciplinary meeting in progress. The previous night the police raided the camp and found in the workers' tent five women from the re-education camp up on the plateau. The women were taken away, the workers left to be disciplined by the geology team.

"They were wild women," says one of the workers.

"They had slept with lions," pipes up another.

"They were so fierce we couldn't refuse them," claims a third. (219) 
The sexual exploitation of the women by African rather than European men gestures toward the colonial continuities of post-independence. The workers' animalization of the women unveils their instrumental use of Frelimo's obsession with cleansing society through the control of women's sexuality to justify their actions: by failing to become New Women, they are corrupting the New Men. As such, only women are to be punished for persisting in a colonial mindset, as replicated in the film when Sadimba finds the soap Felisberto had given to Ancha. Maria João's inability to respond to the occurrence in any way other than by punishing the detainees demonstrates the efficacy of Frelimo's posture in preventing women from conceptualizing emancipation on their own terms.

The emergence of solidarity between the detainees and, later, between the female soldiers and detainees is only made possible through the sacrifice of Margarida. It soon becomes clear to both groups that Margarida does not belong in the camp. Once it is acknowledged that she is a virgin, the detainees strike a deal with the female soldiers. They will cease resisting and perform like transformed New Women with clean heads when Commander Felisberto comes to inspect the camp if he takes Margarida back home to her family. As the only person who can decide if the detainees are ready to be integrated into the New Society as New Women, Felisberto attempts to use this power to get Rosa, an outspoken prostitute from Maputo, to spend the night with him. Performing like a New Woman, Rosa reports the case to Maria João, but refuses to challenge Felisberto openly through denunciation, in the hope that this will ensure Margarida's safe return home. The outcome is the opposite. The women's failure to denounce Felisberto as a "reactionary" reinforces his ability to use Margarida as he wishes. When confronting Maria João, in the aftermath of Margarida's return to the camp, Rosa states:

Nós aprendemos tudo o que nos ensinaram aqui. Aprendemos a marchar, a abrir estrada, a cozinhar: aprendemos, sim.... Não tenho medo de si. E, já agora, está na altura de nos provar que é aquela mulher com tomates que nos disse naquela altura em que chegamos aqui "Sou Maria João. Comandante Maria João. Sou uma mulher, mas posso ser um homem muito mau para quem não me obedecer, ouviram?" Tira-nos daqui e vamos dar porrada naquele filho da puta. Ele, sim, é pior que colono. 
This moment, in which Maria João and the remaining female soldiers are confronted with the performance of the New Woman ideal is also a moment of revelation in which they recognize the pitfalls of Frelimo's socialist revolution for all Mozambican women. All the women abandon the re-education camp and walk towards the village, in pursuit of Felisberto, in a move that suggests "a luta por uma nova identidade de género" that would come to mark the years following the socialist revolution (Casimiro 76). The fact that throughout this walk Margarida picks berries that she knows are poisonous, however, places a shadow over the celebratory tone, and reminds the viewer that only one battle has been won, and not the war.

\section{The importance of remembering: the work of art and its context}

Virgem Margarida's proposal to revisit history and the processes through which collective memories come to be constructed and crystalize allows for the opening of a space of reflection on the relationship between the film and the specific context from which it emerges. As Warburg reminds us, the former cannot be fully understood independently from the latter. Considering the historical developments in Mozambique since its problematic socialist experiment, one cannot help but wonder about the relevance of invoking the memory of such a period in the context of 2012-the year Mozambique celebrated the twentieth anniversary of the signing of the 1992 General Peace Accord that put an end to the internal conflict between Frelimo and Renamo. This is particularly so in light of the escalating political and military crisis that has dominated Mozambique since 2012, with Renamo's intermittent threats to return to violence and repeated attacks perpetrated by their sympathizers in the center of the country. Confino's view of memory "as an outcome of the relationship between a distinct representation of the past and the full spectrum of symbolic representations available in a given culture" immediately directs us to the analysis of the links between the work of art itself and the universe of social experiences within the specific society under scrutiny (1391). By focusing on tensions motivated by competing ethnic and regional identities, my claim is that the recovery of marginalized memories, through the recognition of women's personal experiences in the context of 2012, is intrinsically linked to what Warburg calls 
"the ideal or practical exigencies of real life" (qtd. in Confino 1391) and, ultimately, aims at allowing for the (re)opening of the debate on national identity.

If it is true that post-internal conflict reconstruction in Mozambique has allowed for the country to be represented internationally as "Africa's success story" at the start of the twenty-first century, it is also true that the same representation was immediately challenged and has been ever since (Jones; Macamo and Neubert; Igreja 239-58). Considering the scope of the current discussion, let us take a step back and focus on the 1992 General Peace Accord, negotiated in Rome, that put an end to more than a decade of violence. According to Victor Igreja, in the aftermath of the signing of the agreement, the rhetoric of both Frelimo and Renamo shifted toward promises of reconciliation, reconstruction, forgiveness, solidarity, tolerance, and trust (247). The accord, Igreja continues, established the planning of democratic elections, the demobilization and reintegration of soldiers from both parties into a new national army, but it did not contemplate plans for an amnesty law or structures for a truth commission (247). This agreement and its outcomes were highly celebrated in different international platforms; however, by 2003 sociologists Elísio Macamo and Dieter Neubert had pointed out the need to understand the accord's limitations and argued that the kind of peace that was achieved might not be a sustainable one. After a detailed examination of the dynamics of the internal conflict in Mozambique, of the emergence of the politics of peace-building (when it became clear that neither party could win the war), and of the development of the negotiations (mediated by the Sant'Egidio Community, a lay Catholic organization), Macamo and Neubert come to the conclusion that the accord was fragile for two reasons. First, peace had to be sold to both parties in exchange for development aid, which raised the issue of what would happen once the money was gone. Second, given that no party was made accountable for the atrocities committed during the war-again, as part of a strategy to persuade both parties to negotiate-violence remained unchallenged as a means to achieve one's goals. This could result in either party resorting to it at a subsequent stage, in extremis, to legitimize their hold on or access to political power. Indeed, time has proved them right.

In the years that followed the signing of the accord, the regional divisions in Mozambique became clear, with Frelimo being vastly supported in the south, and Renamo in the central and northern provinces (Newitt 218). It has also become 
clear that despite the fact that Renamo has affirmed itself as a legitimate opposition party, Frelimo has maintained sole access to real political power and development funds. In 2005, Armando Guebuza became Mozambique's third president, winning a comfortable victory over his opponent. The new Frelimo government that emerged under his leadership strengthened its grip on absolute political power. Guebuza imposed mandatory retirement on high-ranking individuals from ex-Renamo military forces without consulting or negotiating with Renamo (Igreja 254-55). This radical tightening of the link between the Frelimo party and military structures is one that replicated the stance of Samora's government in order to ensure Frelimo's authority over the military (Machava 597). According to Borges Coelho and Macaringue, during Samora's presidency, "serving in the army became the highest guarantee of political trust," a reality that Frelimo aimed to repeat in the political context of 2005 (qtd. in Machava 597). Renamo grew impatient towards what the party viewed as "fifteen years of democratic stagnation," and increasingly toughened its rhetoric and positioning, culminating in Afonso Dlhakama (Renamo's leader) leaving Maputo in 2009first for Nampula and later to settle in Sofala with the aim of organizing his supporters and preparing for war (Igreja 254). Igreja argues that as the years went by, mutual perceptions and relations between both parties remained antagonistic, and both resorted to the use of specific memories of the civil conflict to make accusations and deny each other's legitimacy (251-53). As he puts it: "The long duration of these accusations has only been possible because of lack of warrelated accountability measures that could have opened up the debate regarding the responsibility of both Frelimo and Renamo and other groups and individuals in society" (254). For Igreja, this lack serves to explain the 2012 return of the armed conflict.

In 2012, both parties once again took up arms, with the central provinces of Sofala and Manica being the main stage for confrontations. The Rome Accord had come to an end. Everyday life across the entire country has been affected by the conflict, and the consequences are visible in multiple ways: in terms of the restrictive circulation of people and goods; of stalled agricultural production; of forced displacement of people; and of casualties on both sides of the conflict (Igreja 240). This climate of political and social instability led various intellectuals and non-governmental organizations to voice their concerns openly about the escalating violence and put pressure on the leaders of both parties to 
negotiate the terms of a new peace accord, which was eventually signed on 5 September 2014. This new accord allowed for the modification of the electoral law, as requested by Renamo, and the creation of a new amnesty law approved by both parties. Ultimately, the signing of the new accord paved the way for general elections in October 2014, which were won by Frelimo's candidate and Mozambique's fourth president, Filipe Nyusi. Renamo immediately claimed that the election results were fraudulent, and to this day they still demand to be allowed to govern the six provinces (Sofala, Manica, Tete, Zambézia, Nampula, and Niassa) in which it claimed victory. Political instability and a climate of suspicion and fear continue to dominate current affairs in Mozambican society in 2016, with both parties increasing militarization and firmly moving away from the commitments made at the time of the signing of the 2014 peace accord.

In this environment of uncertainty, it is possible to observe a return to the use of war memories in the rhetoric of both parties as they seek to legitimize their position. Both parties are using discourses of identity, built on simplified notions of historical antagonism, as a political tool to assert their entitlement to power. For its part, Frelimo has returned to labeling Renamo as terrorists, enemies of the Mozambican people who are financed by external forces and therefore have no legitimacy (Chavisso). In turn, Renamo blames Frelimo for their continuous need to resort to violence, and insists on a belligerent, threatening, and separatist rhetoric as the only means to bring about political change (Caldeira). The conflict continues without an end in sight, and it has already claimed numerous victims. The number of casualties and dislocated people continues to rise, and reports of human rights violations are increasingly frequent (Silva). Once again, the ghost of national identity returns to haunt Mozambique, pointing at the need to rethink it so that a different future might be imagined.

National identity is one of the main issues explored throughout Virgem Margarida, through the discussion of Frelimo's imposed "New Society." The deconstruction of the "New Woman" profile unveils national identity as a powerful fiction, which, as Anne McClintock reminds us, is gendered, invented, and dangerous (352). In the movie, however, the problematization of identity is expanded by adding other elements of identification to the discussion of gender constructions, namely perceptions of ethnic and regional affiliation. At the beginning of the film, we accompany the group of women coming from the urban South on their journey to the North (most re-education camps were established 
in the Northern province of Niassa). The North itself had by this time been reimagined as a place for punishment. ${ }^{3}$ Later, these regions would be associated with Renamo, as the re-education camps turned into important hubs for their recruitment of fighters and supporters (Machava 593-609).

The first encounter between the Southern and the Northern women in Virgem Margarida sets the conflicting tone of their relationship throughout the film. On arrival at the camp, the Southern women see another group of women sitting under a tree. The emphasis is immediately put, at this stage, on the differences between both groups. The Northern women are wearing capulanas and mussiro masks, which suggests they are Macua, from the region of Nampula. Known as muthiana orera, these women are stereotyped as the most beautiful in Mozambique. The camera then follows Rosa as she approaches Ansha with a challenging attitude. Their first exchanges denote suspicion toward each other: Rosa looks down on Ansha, asking about her culture in an ironic tone, mocking her mussiro mask and accent, and calling her provincial; Ansha responds in the same challenging tone, defying Rosa's urban arrogance, and highlighting that Rosa knows nothing about her region, which has great cities too. Soon, the two women engage in a physical altercation, incited by the other women. The terms of the animosity between the two groups are established in quite a simplified way. The two women dislike each other due to preconceptions they have about each other's cultural backgrounds. It is important to bear in mind that the film begins with the introduction of the group of Southern women and accompanies their trajectory and development in more detail, which immediately suggests sympathy towards their plight as opposed to that of the other women. The group of Northerners is represented merely as the opposing force to the Southerners, a gesture suggestive of a very simple binary opposition - at least initially.

As the film develops, its one-dimensional representations of both Northern and Southern women's identities are revealed to be nothing but misconceptions, and it becomes clear that the conflict between them is not an identity-based one, as might have been previously suggested. The outspoken Rosa, for example, initially appears to be merely a bully who cares about nothing and no one but herself. She steals from the other inmates, constantly threatening them with

\footnotetext{
${ }^{3}$ LeFanu recalls that even one of Samora's adolescent daughters was sent to Niassa after becoming pregnant. In the end, she was forced to marry the father of her baby (221).
} 
violence, and takes pleasure in scaring them. When all the women are bathing at the river, for example, she pretends to have spotted a crocodile just to see the frightened women run. She is also the strongest voice of resistance against the indoctrination of the female soldiers, which results in her being severely punished several times. As time evolves, she reveals a caring nature towards Luísa, Susana, and Margarida. Ultimately, she is the one who speaks for the entire group when the inmates negotiate Margarida's departure with the female soldiers. Susana evolves similarly. She is a single mother who is also a dancer at a famous hotel in Maputo. Initially, she appears to be somewhat snobbish in relation to her peers. She wears a long red evening dress and is the only one wearing leather boots. She also reminisces about her house and its blue walls, which clearly indicates her different economic status. She often defends her innocence, on the grounds that dancing is not a crime, to distinguish herself from the other women. Later on, however, this one-dimensional representation of Susana becomes dismantled. When Laurinda dies due to a lack of medical assistance, Susana is punished for grieving over her death. Her punishment is to dig Laurinda's grave herself. Her thoughts are always with her children, and when she learns about the death of one of them, she immediately escapes the camp alone. In the end, she is killed by a wild animal.

The Northerners Ansha and Mariamu are also portrayed in a very stereotypical fashion throughout most of the film. From the moment when the rivalry between Northerners and Southerners is established, they are represented as the enemy in the narrative, attacking and undermining the group of Southern women on various occasions. For example, Mariamu, following the soldiers' orders for intergroup surveillance, reports Rosa's subversive behavior to them, thus prompting the latter's punishment. An even more expressive example is the scene in which Ansha volunteers to choose a punishment for Susana after the latter fails to reach the latrine on time: "Camarada Comandante, essa aí tem manias. É bom punir-lhe mesmo.” Ansha states that Susana must be punished for being a snob, and the selected punishment is thus a humiliating one: Susana must run and crawl around in circles repeating "Eu fiz cocó na caserna."

As the film unfolds, it complicates the one-dimensional representation of both groups. When the Southern women decide to escape, they meet a Northern peasant on the way whom they ask for help. Because they are so hungry, Rosa asks the peasant for some peanuts in exchange for sex with one of the women in 
the group. The episode echoes an earlier one in the movie, in which the Northerner Ansha seduces and sleeps with Felisberto in exchange for a bar of soap, which she shares only with Mariamu. The behavior of all the women thus emerges not as something predetermined by their original identity, but by their struggle for survival and access to a sense of security, and power, in such an inhospitable environment.

Three main conclusions can be taken from Virgem Margarida's treatment of the theme of identity. On one level, by dismantling simplified versions of ethnic and regional identities, the movie alerts us to the imagined nature of identity and its effectiveness, as a discursive tool, for politics. On a second level, it shows us how oppressive and dangerous these constructed subjectivities can be. Finally, it proposes challenging identity, given that rethinking it exposes the struggle of the ruling elites for the maintenance of or access to power, which is particularly relevant in light of the sociopolitical situation of Mozambique in 2012. It is Margarida who allows for the emergence of a platform of renegotiation within the group of detainees, when all the women finally unite in their efforts to prove that she is, in fact, a virgin. The women's push for the acknowledgement of Margarida's virginity represents the beginning of the failure of the New Woman ideal and the regime behind it: Margarida did not belong in the camp and she deserved a different future. When the female soldiers ultimately recognize the limitations of this constructed subjectivity, all the women successfully open the way for the emergence of alternative identities, created by themselves and determined by their own choices.

\section{Conclusion}

Virgem Margarida provides a powerful account of one of Frelimo's most controversial and poorly understood socialist programs in the period immediately following Mozambican independence. By retrieving individual memories of the period, voiced by different women, the movie allows for what Paul de Ricoeur calls the "narrative configuration" of a moment in history that was previously narrated in a very specific light so as to reflect the program of a political elite (448). Giving these female characters, as social actors, the opportunity to bring forward their own versions of that memory disturbs and to a certain extent corrects the official history of the re-education camps. At the same time, the study 
of the movie within its context of emergence allows for the act of remembering to become urgent, as the means to avoid making the future a place for repetitions of the flawed past. Finally, by focusing on the deconstruction of imagined female subjectivities through women's powerful engagement, Virgem Margarida points to the need to dismantle oppressive identity constructions to permit the creation of alternative and more inclusive communities in contemporary Mozambique.

\section{Works Cited}

Azevedo, Licínio de. "Construir Salas de Cinema em Moçambique Pode Ser Um Investimento Arriscado.” @Verdade 25 April 2013. Web. 1 Mar. 2016.

-. "Do jornalismo ao cinema: em Entrevista com o Realizador Licínio de Azevedo.” O País 3 June 2014. Web. 1 Mar. 2016.

-. "Reeducação de Mulheres: Entrevista a Licínio Azevedo sobre o Filme Virgem Margarida." Buala 13 Sep. 2012. Web. 1 Mar. 2016.

-. Relatos do Povo Armado. Vol. 1. Maputo: Cadernos Tempo, 1983. Print.

—, dir. Virgem Margarida. Ebano Multimedia. 2012. Film.

—, and Maria da Paz Rodrigues. Diário da Libertação: A Guiné-Bissau da Nova África. São Paulo: Versus, 1977. Print.

Caldeira, Adérito. "Partidos Frelimo e Renamo dizem querer a paz mas continuam em guerra.” @Verdade 18 Feb. 2016. Web. 1 Mar. 2016.

Casimiro, Isabel Maria. "Samora Machel e as Relações de Género." Estudos Moçambicanos 21 (2005): 55-84. Print.

Chavisso, Estêvão Azarias. "Frelimo acusa Dhlakama de assumir postura terrorista em Moçambique.” Agência Lusa 4 Sept. 2015. Web. 1 Mar. 2016.

Confino, Alon. "Collective Memory and Cultural History: Problems of Method." The American Historical Review 102.5 (1997): 1386-403. Web. 1 Mar. 2016.

Convents, Guido. Os Moçambicanos Perante o Cinema e o Audiovisual: Uma História Político-Cultural do Moçambique Colonial Até à República de Moçambique (1896-2010). Maputo: Conteúdos e Publicações, 2011. Print.

Cordeiro, Ana Dias. "O Inimigo de Dentro da Revolução." Público 22 Nov. 2013. Web. 1 Mar. 2016.

Darch, Colin. "Centros de Reeducação, 1974-." Mozambique History Net. Dossier MZ-0318. Web. 1 Mar. 2016. 
-. "Machel's Speech on Unjust Detentions in Re-Education Camps." Mozambique History Net. Summary of World Broadcasts [London], ME/6846, 6 October 1981, p. B/1. Web. 1 Mar. 2016.

Ferreira, Ana Paula. "Home Bound: The Construct of Femininity in the Estado Novo." Portuguese Studies 12 (1996): 133-44. Print.

Gray, Ros. "Cinema on the Cultural Front: Film-Making and the Mozambican Revolution." Journal of African Cinemas 3.2 (2011): 139-60. Print.

Igreja, Victor. "Amnesty Law, Political Struggles for Legitimacy and Violence in Mozambique." International Journal of Transitional Justice 9 (2015): 23958. Web. 1 Mar. 2016.

Isaacman, Barbara, and June Stefhan. A Mulher Moçambicana no Processo de Libertação. Maputo: INLD, 1984. Print.

Jones, Branwen Gruffydd. "Appearances and Realities of Post-War Reconstruction in Mozambique." Portuguese Literary and Cultural Studies 10 (2003): 49-67. Print.

LeFanu, Sarah. S is for Samora: A Lexical Biography of Samora Machel and the Mozambican Dream. New York: Columbia UP, 2012. Print.

Macamo, Elísio, and Dieter Neubert. "The Politics of Negative Peace: Mozambique in the Aftermath of the Rome Cease-Fire Agreement." Portuguese Literary and Cultural Studies 10 (2003): 23-47. Print.

Machava, Benedito Luís. "State Discourse on Internal Security and the Politics of Punishment in Post-Independence Mozambique (1975-1983)." Journal of Southern African Studies 37.3 (2011): 593-609. Web. 1 Mar. 2016.

McClintock, Anne. Imperial Leather: Race, Gender, and Sexuality in the colonial contest. London: Routledge, 1995. Print.

Mosca, João. Economia de Moçambique: Século XX. Lisbon: Instituto Piaget, 2005. Print.

Newitt, Malyn. "Mozambique." A History of Postcolonial Lusophone Africa. Ed. Patrick Chabal, et al. London: Hurst, 2002. 185-235. Print.

Nhantumbo, Sonia, and Maria Paula Meneses. "Inventário das Actividades com Abordagem de Género em Cursos Realizados na UEM nos Últimos 25 Anos." Estudos Moçambicanos 21 (2005): 105-29. Print.

Owen, Hilary. Mother Africa, Father Marx: Women's Writing of Mozambique 1948-2002. Lewisburg: Bucknell UP, 2007. Print. 
Renan, Ernest. "What is a Nation?" Nation and Narration. Ed. Homi Bhabha. New York: Routledge, 1990. 8-22. Print.

Ricoeur, Paul. Memory, History, Forgetting. Trans. Kathleen Blamey and David Pellauer. Chicago: U of Chicago P, 2004. Print.

Rothwell, Phillip. "Introduction: Reevaluating Mozambique." Portuguese Literary and Cultural Studies 10 (2003): xi-xx. Print.

Scott, Catherine V. Gender and Development: Rethinking Modernization and Dependency Theory. London: Rienner, 1995. Print.

Sheldon, Kathleen E. Pounders of Grain: A History of Women, Work, and Politics in Mozambique. Portsmouth, UK: Heinemann, 2002. Print.

Silva, Guilherme Correia da. "Human Rights Watch: Exército de Moçambique Executa e Viola em Tete." Deutsche Welle 23 Feb. 2016. Web. 1 Mar. 2016.

Urdang, Stephanie. And Still They Dance: Women, War, and the Struggle for Change in Mozambique. London: Earthscan, 1989. Print.

Yeboah, Nina. "Resilient Whores and Broken Virgins: A Review of Virgin Margarida." Shadow \& Act: On Cinema of the African Diaspora. Indiewire. 17 June 2014. Web. 1 Mar. 2016.

Zawangoni, Salvador André. A Frelimo e a Formação do Homem Novo (19641974 e 1975-1982). Maputo: CIEDIMA, 2007. Print. 